Колісник Г.М., Диха М.В.

\title{
ФОРМУВАННЯ ЕФЕКТИВНОЇ СИСТЕМИ РЕГУЛЮВАННЯ ВИТРАТАМИ ЯК ЧИННИКА ЕКОНОМІЧНОЇ БЕЗПЕКИ ПІДПРИЕМНИЦТВА
}

\begin{abstract}
Досліджено передумови формування ефективної системи регулювання витратами як чинника економічної безпеки підприємництва. Розглянуто структуру національної системи економічної безпеки підприємництва та запропоновано систему регулювання витратами як чинника економічної безпеки підприємництва та ї̈ структурні елементи. Запропоновано комплекс інструментів, шзо забезпечують регулювання витратами підприємництва, також представлено рівні та складові системи регулювання витратами як чинника економічної безпеки підприємництва та запропоновано напрями реалізації заходів державної політики регулювання витратами як чинника економічної безпеки підприємниџтва в Украӥні.
\end{abstract}

Ключові слова: економічна безпека підприємництва, ефективна система регулювання витратами підприсмництва, структурні елементи регулювання витратами, складові системи регулювання витратами, заходи державної політики регулювання витратами.

Постановка проблеми. Сучасна макроекономічна ситуація обумовила необхідність формування ефективної національної системи регулювання витратами як чинника, що дозволяє керувати економічною безпекою підприємництва. Адже нинішній стан, в якому опинилося національне господарство України, описується як політичною, так і економічною нестабільністю, що супроводжуються частими змінами цілей макроекономічної політики, ускладнюється недосконалістю правового забезпечення підприємницької діяльності. Існуючі умови перетворили такий структуроутворюючий сектор національної економіки, як підприємництво у сферу діяльності, яка існує в небезпечному середовищі.

В умовах, що склалися, все більшої актуальності набуває проблема регулювання витратами підприємництва як визначального сектора національної економіки, котрий виконує соціально-економічні функції. Економічна безпека підприємництва незалежно від рівнів економічних відносин трактується як здатність комплексної та узагальненої системи безпеки реалізувати можливості щодо її гарантування та забезпечення. Тому в умовах економічних перетворень в Україні, постійних змін в економічній і політичній ситуації, актуальність формування ефективної системи регулювання економічною безпекою підприємництва зростає. Особливо зростає потреба у створенні ефективних систем та механізмів регулювання витратами, котрі

(C) Колісник Галина Миколаївна, д.е.н., доц., професор кафедри обліку i аудиту, ДВНЗ «Ужгородського національного університету», тел.: +380501930067, e-mail: kolisnuk_galina@mail.ru Диха Марія Василівна, д.е.н., доц., професор кафедри економіки підприємства і підприємництва, Хмельницького національного університету, тел.: +380975829701, e-mail: dyha-mv@ukr.net виступають чинниками формування економічної безпеки підприємництва. Для цього необхідний інтенсивний розвиток теоретичних, методологгічних, методичних та правових основ забезпечення регулювання витратами цього структуроутворюючого сектора економіки.

Аналіз останніх досліджень і публікацій. У наукових дослідженнях М. М. Єрмошенко [1] та Е. А. Олейникова [2] розглядаються такі складові економічної безпеки, як: інтелектуально-кадрова, фінансова, техніко-технологічна, політикоправова, екологічна, інформаційна та силова складові економічної безпеки підприємництва [1].

У своїх працях Г. А. Пастернак-Таранушенко здійснює більш детальну класифікацію складових економічної безпеки підприємництва, а саме: демографічну, екологічну, продовольчу, військову, ресурсну, прісноводну, енергетичну, цінову, фінансово-грошову, політичну, соціальну, кримінальну, медичну та інформаційну складові [3].

Проте окрім окреслених провідними науковцями складових економічної безпеки підприємництва, на нашу думку, необхідно враховувати також на секторальні, галузеві та регіональні складові. Адже основною метою формування ефективної системи регулювання економічною безпекою підприємництва $€$ забезпечення його ефективного функціонування та нівелювання (убезпечення) ймовірних загроз та ризиків.

Формування цілей статті. Мета статті полягає у дослідженні ефективної системи державного регулювання економічної безпеки підприємництва.

Опис основного матеріалу дослідження. Для формування ефективної системи регулювання витратами як чинника економічної 
безпеки підприємництва слід визначити ряд окремих передумов:

1. Дана система може трактуватися як типова модель та виступити шаблоном для побудови базової моделі для конкретного сектору економіки, регіону та національної економіки, однак тільки за умов врахування специфічних галузевих та регіональних особливостей розвитку.

2. Система регулювання витратами як чинника економічної безпеки підприємництва може функціонувати як окремий елемент в загальній структурі економічної безпеки галузі, регіону, сектору, національної економіки;

3. Система регулювання витратами як чинника економічної безпеки підприємництва має включати функціональні складові, організаційні структури та ресурси, що сформовані на основі сучасних наукових досягнень в сфері безпеки підприємництва.

На рис. 1. представлена структура національної системи економічної безпеки підприємництва, котра включає в себе дві підсистеми: підсистему державного забезпечення та підсистему недержавного забезпечення. Отже, економічна безпека підприємництва загалом, характеризується тим, що забезпечує ефективну діяльність підприємництва щодо протидії зовнішнім та внутрішнім впливам та загрозам, сприяе захисту економічних інтересів підприємництва, створює безпечні умови функціонування підприємництва на рівні нормативно-визначених показників, не дає зростати витратам підприємництва.

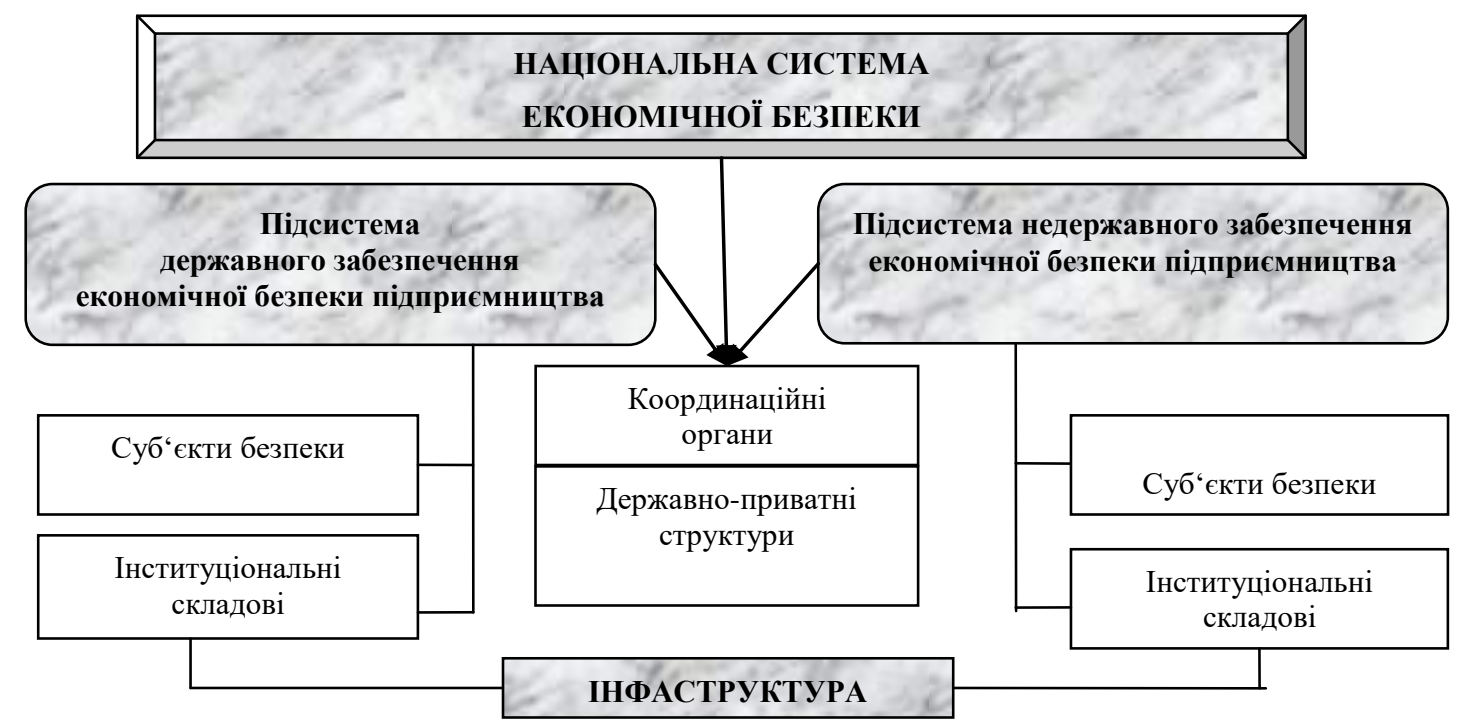

\section{Рис. 1. Структура національної системи економічної безпеки підприємництва* \\ * Розробка авторів}

Оскільки економічна безпека підприємництва $\epsilon$ складовою національної економічної безпеки, то на наш погляд, у вигляді іï функціональних складових слід виділяти всі складові національної економічної безпеки, що здійснюють системний вплив на процес її забезпечення.

Відповідно систему регулювання витратами підприємництва слід ідентифікувати як складову економічної безпеки підприємництва, що в свою чергу виступає елементом комплексної національної економічної безпеки як об'єкт державного макроекономічного регулювання. 3 іншого боку, система регулювання економічною безпекою підприємництва виступає суб'єктом національної економічної безпеки, тим самим автоматично забезпечуючи безпеку такого структурного елемента економіки як підприємництво.

За таких умов для формування ефективної системи регулювання витратами 3 метою забезпечення економічної безпеки підприємництва варто враховувати наступні умови: 1) циклічність в розвитку вітчизняної економіки; 2) особливості трансформаційних процесів; 3) комплексність у використанні підходів при виборі векторів розвитку.

Від врахування перерахованих умов залежить вибір інструментів, методик і моделей регулювання витратами як чинника економічної безпеки підприємництва, що в умовах невизначеності зовнішнього середовища дає змогу визначити перспективи формування ефективної системи, зважаючи на ризики [4].

Для побудови ефективної системи регулювання витратами підприємництва перевага повинна віддаватися стратегічному підходу. Вибір на стратегічному підході зроблено не випадково. Справа в тому, що розуміння стратегічної природи вибудовування ефективної системи регулювання витратами як чинника економічної безпеки підприємництва 
спонукає до реального оцінювання існуючих очікувань та надає можливість вибудувати адекватну відповідь на ці сподівання.

Тому перед національною системою постає завдання не точкового впровадження регулюючих елементів, а побудова та розгортання цілої системи регулювання витратами підприємництва (рис. 2.), що є невід'ємною частиною національної економічної безпеки підприємництва.

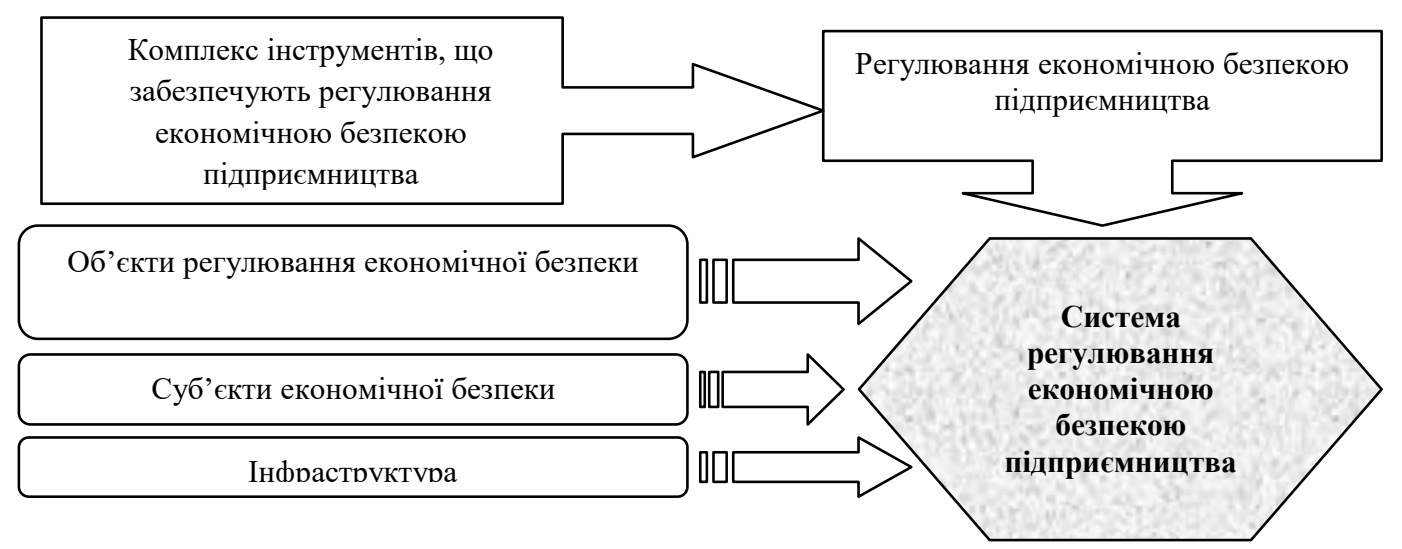

Рис. 2. Система регулювання витратами як чинника економічної безпеки підприсмництва*

* Розробка авторів

Як бачимо 3 рис. 2. для формування ефективної системи регулювання витратами підприємництва необхідно спершу визначити структурні елементи цієї системи, відштовхуючись від класичного розуміння поняття «система». Зважаючи на це, розкриємо основні структурні елементи системи регулювання витратами як чинника економічної безпеки підприємництва (рис. 3.).

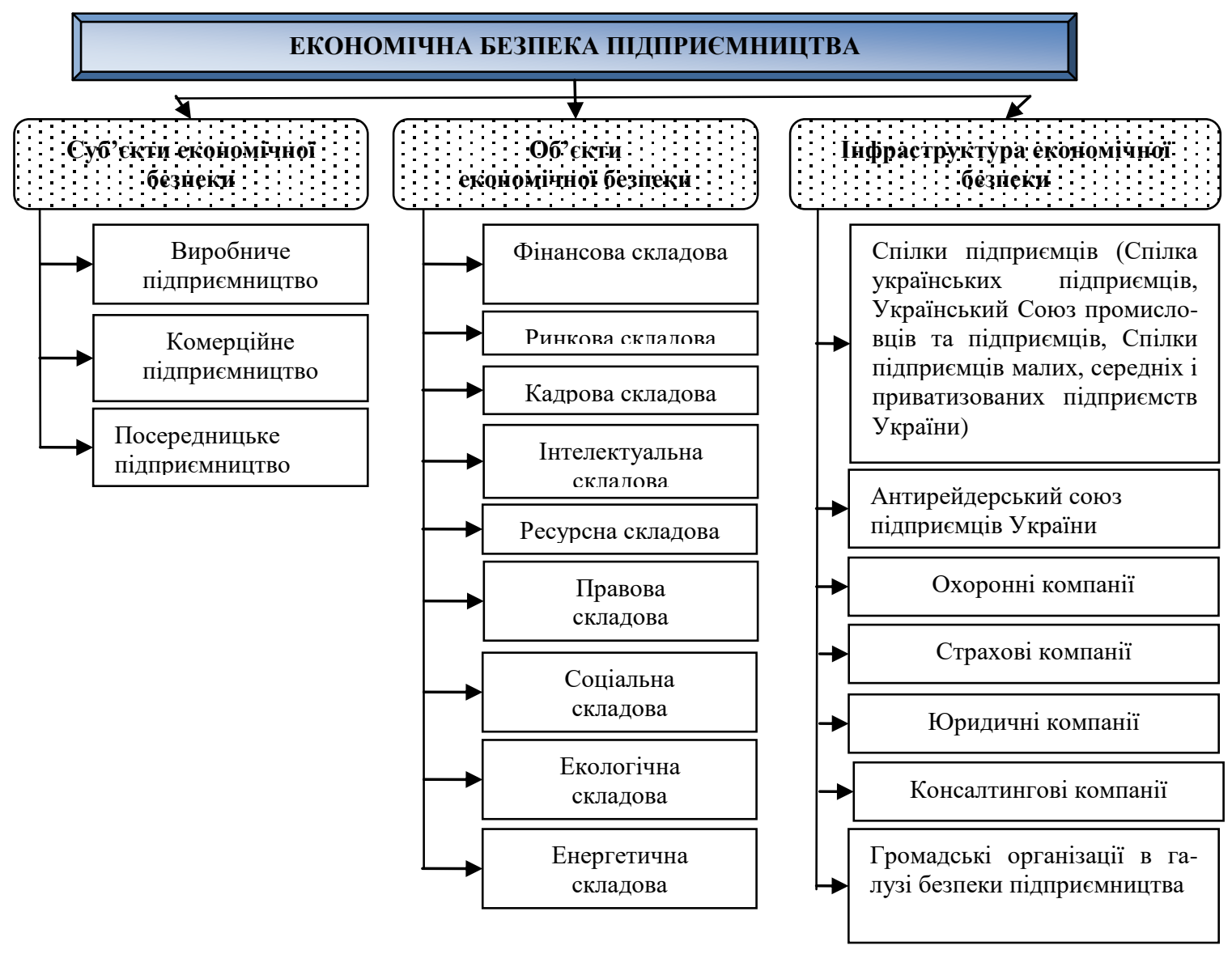

Рис.3. Структурні елементи системи регулювання витратами як чинника економічної

* Розробка авторів безпеки підприємництва 
Система регулювання витратами як чинника економічної безпеки підприємництва включає також певний комплекс інструментів, що уможливлюють здійснення даного регулювання на різних рівнях державного управління.
На наше переконання, весь комплекс визначених інструментів регулювання витратами підприємництва доцільно згрупувати за інститутами державного та ринкового регулювання економічною безпекою підприємництва (рис.4).

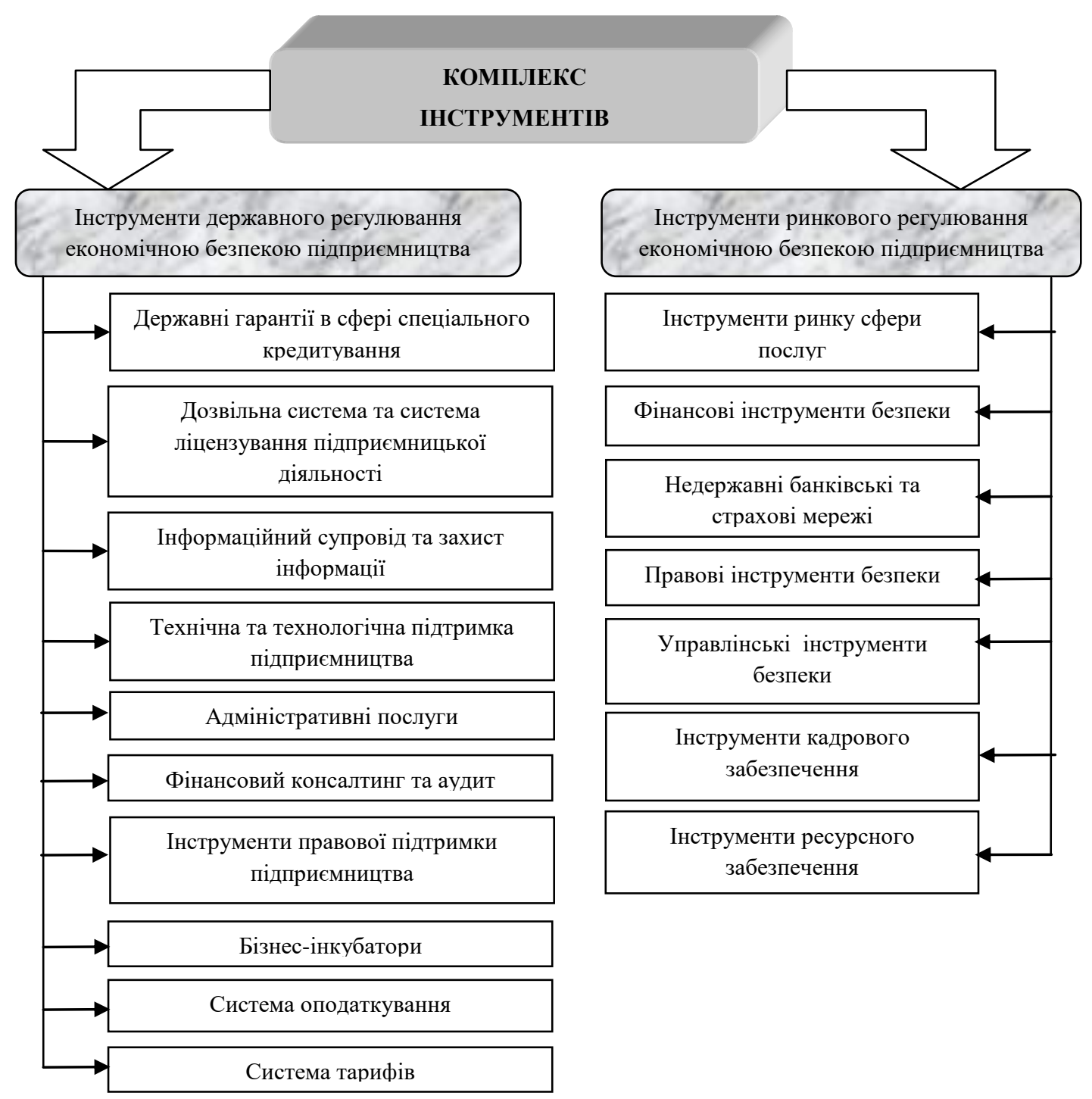

Рис.4. Комплекс інструментів, що забезпечують регулювання витратами підприємництва*

* Розробка авторів

Як ми вже зазначали, необхідність формування ефективної системи регулювання витратами як чинника економічної безпеки підприємництва пояснюється соціальноекономічним призначенням даного сектора економіки та його розмірами.

Для України актуальність підвищення ефективності системи регулювання економічною безпекою підприємництва значно зростає в зв'язку 3 посиленням процесу інтеграції до європейського економічного простору та недосконалістю i низькою результативністю державної політики в цій сфері.

Побудова ефективної системи регулювання витратами підприємництва має відбуватися на різних рівнях ієрархії системи регулювання економікою 3 урахуванням галузевих відмінностей. На рис. 5. представлені рівні та складові системи регулювання витратами як чинника економічної безпеки підприємництва. 


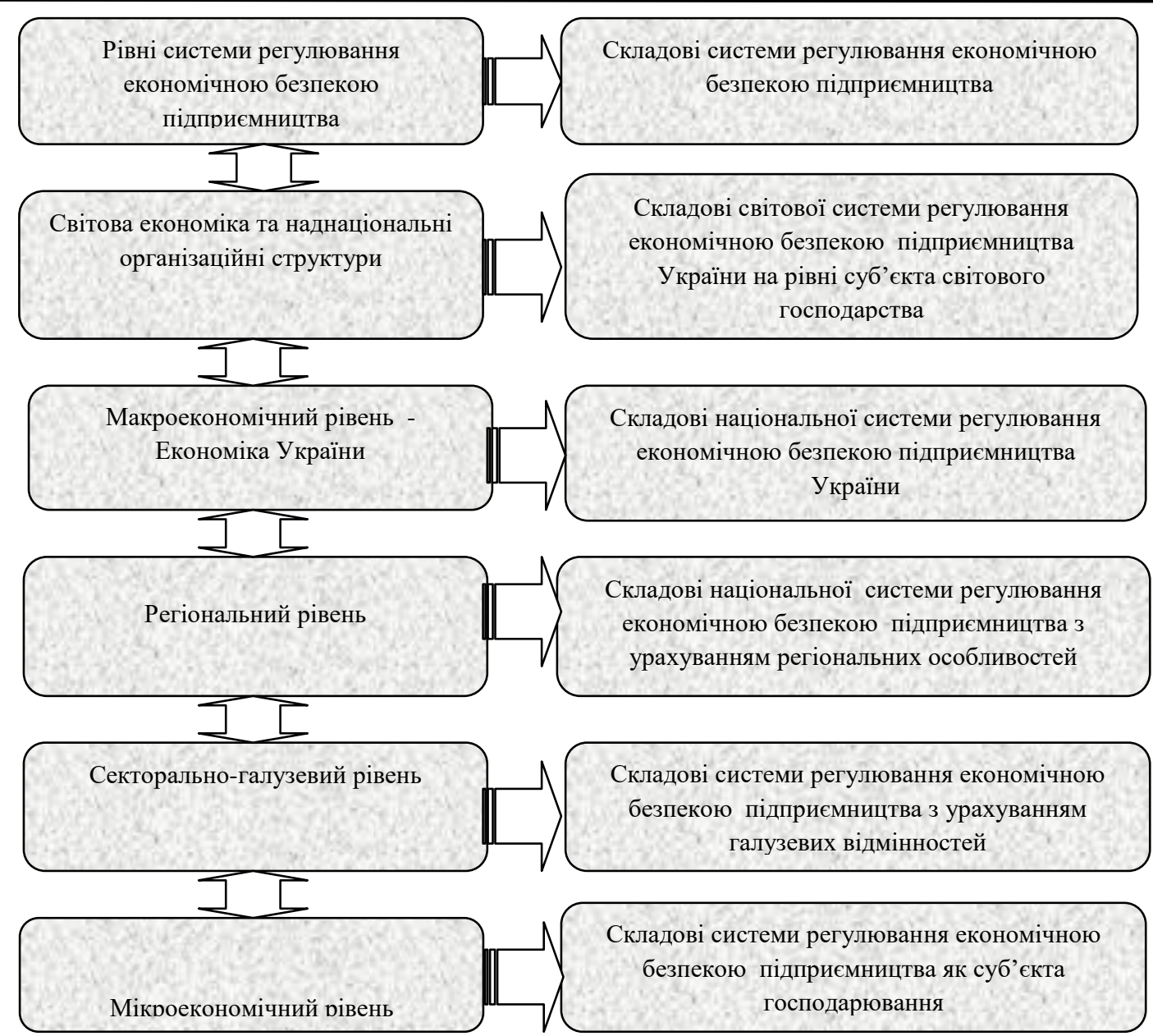

Рис. 5. Рівні та складові системи регулювання витратами, як чинника економічної безпеки

* Розробка авторів підприсмництва*

Наразі в Україні центральним органом виконавчої влади, що здійснює державну політику розвитку підприємництва, є Державна регуляторна служба України [5] та ряд недержавних структур. Серед недержавних структур слід виділити такі громадські організації, як: «Спілка українських підприємців», «Український Союз промисловців та підприємців», «Спілка підприємців малих, середніх і приватизованих підприємств України», «Антирейдерський Союз України», численні регіональні відділення спілок підприємців, а також система підприємств, установ та організацій, які утворені для надання підтримки стосовно безпеки підприємництва у фінансовій, матеріально-технічній, інформаційній, науково-технологічній, консультативній, маркетинговій, кадровій, освітній сферах.

Проте незважаючи на всю різноманітність недержавних структур та наявність відповідного державного органу, система регулювання економічною безпекою підприємництва $\epsilon$ недосконалою та неефективною, а в частині регулювання витратами підприємництва i поготів. Вказане твердження доводиться наступними фактами:

1. Відсутністю реальних механізмів регулювання витратами підприємництва. Даний факт ускладнюється тим, що відсутня, в першу чергу, національна стратегія економічної безпеки підприємництва, складовою котрої мала б стати система регулювання витратами як чинника економічної безпеки підприємництва.

2. Недостатність кадрового забезпечення та владних повноважень центрального органу виконавчої влади - Державної регуляторної служби України та недержавних структур на регіональному і місцевому рівнях стосовно регулювання економічною безпекою підприємництва загалом та витратами в тому числі.

3. Недостатність фінансового забезпечення системи регулювання економічною безпекою підприємництва, оскільки оплата заходів щодо підтримки підприємництва здійснюється 3 допомогою бюджетної системи. А інституційна база національної бюджетної системи побудована за принципом централізації і по своїй суті не $\epsilon$ орієнтованою на таке фінансування. 
4. Організаційна незабезпеченість системи регулювання витратами підприємництва стосовно дозвільної системи, антимонопольної політики, ліцензування, нагляду (контролю) у сфері господарської діяльності та дерегуляції господарської діяльності, захисту прав інвесторів.

5. Недосконалість системи ліцензування та надання дозволів за рахунок присутності внутрішніх колізій та неузгодженостей в Законі України «Про ліцензування видів господарської діяльності» [6]. Так, наприклад, $50 \%$ від загальної кількості скарг, що надійшли до експертно-апеляційної ради 3 питань ліцензування при Державній регуляторній службі України, виявилися обгрунтованими. У 2015 p. найбільша кількість скарг суб'єктів господарювання надійшла на дії Державної архітектурно-будівельної інспекції України - 12 одиниць, 11 (тобто 90\%) були обгрунтованими [7].

6. Відсутність основ захисту підприємництва від економічної злочинності та організованих правопорушень в економічній сфері, зокрема: кримінально-правових, процесуальних, фінансово-фіскальних засобів.

7. Недотримання експертизи або погодження проектів нормативно-правових актів у сфері державного регулювання підприємництва. Зокрема, в 2015 р. 40\% 3479 проектів, котрі надійшли до місцевих органів виконавчої влади, не відповідали принципам державної регуляторної політики. Серед центральних органів виконавчої влади продовжують порушувати принцип прозорості наступні органи: Мінагрополітики, Державна служба України 3 надзвичайних ситуацій, Мінприроди, Мінекономрозвитку, Міненерговугілля, Мінінфраструктури, Мінкультури, Фонд держмайна, Міноборони, Мінфін, Мінсоцполітики, Державна фіскальна служба України, Мінюст, Держатомрегулювання, Національна комісія, що здійснює регулювання у сфеpax енергетики та комунальних послуг, Національна комісія, що здійснює державне регулювання у сфері зв'язку та інформатизації [7].

8. Застосування державою світового досвіду стосовно способу реалізації господарської політики у сфері боротьби 3 криміналізацією економіки шляхом розробки $\mathrm{i}$ реалізації нормативно-правових засад.

9. Наявність значної частки тіньових схем та операцій, що негативно впливає на загальний стан економічної безпеки підприємництва.

10. Відсутність у недержавних структур та регіональних відділень спілок підприємців, а також існуючих суб'єктів інфраструктури стосовно надання підтримки безпеки підприємництва, інструментів впливу на рішення органів державного та місцевого управління.

$$
\text { 11. Низька якість інформаційного }
$$
забезпечення економічної безпеки підприємництва.

Для подолання вищенаведених негативних аспектів у регулюванні економічною безпекою підприємництва загалом та регулювання витратами підприємництва вважаємо доцільним визначити перелік конкретних заходів. Їх реалізація в системі визначеної державної політики регулювання витратами як чинника економічної безпеки підприємництва має відбуватися за напрямами, що визначені в таблиці 1.

Таблиця 1

\section{Напрями реалізації заходів державної політики регулювання витратами} як чинника економічної безпеки підприсмництва в Україні [8]

\begin{tabular}{|c|c|}
\hline Напрями регулювання & $\begin{array}{c}\text { Заходи державної політики регулювання витратами як чинника } \\
\text { економічної безпеки підприсмництва } \\
\text { за напрямами діяльності } \\
\end{array}$ \\
\hline $\begin{array}{l}\text { Макроекономічні } \\
\text { характеристики } \\
\text { підприємництва }\end{array}$ & $\begin{array}{l}\text { а) зростання основних кількісних та якісних показників розвитку } \\
\text { підприємництва; } \\
\text { б) спрощення дозвільної системи; } \\
\text { в) зниження рівня тінізації і монополізації економіки; } \\
\text { г) посилення кримінальної та адміністративної відповідальності за } \\
\text { протиправні та дискримінаційні дії щодо субб'єктів підприємництва; }\end{array}$ \\
\hline $\begin{array}{l}\text { Фінансова безпека } \\
\text { підприємництва }\end{array}$ & $\begin{array}{l}\text { а)фінансове сприяння підприємництву (державні інвестиції, державно- } \\
\text { приватні банки, фінансова кооперація тощо); } \\
\text { б)зниження рівня податкового навантаження; }\end{array}$ \\
\hline
\end{tabular}




\begin{tabular}{|c|c|}
\hline $\begin{array}{l}\text { Експортний потенціал } \\
\text { підприємництва }\end{array}$ & $\begin{array}{l}\text { а) спрощення правил та процедури експорту вітчизняних товарів до країн } \\
\text { СС та СНД; } \\
\text { б) розширення квот на експорт українських товарів; } \\
\text { в) спрощення системи відшкодування ПДВ експортерам; }\end{array}$ \\
\hline $\begin{array}{l}\text { Інвестиційне } \\
\text { середовище } \\
\text { підприємництва }\end{array}$ & $\begin{array}{l}\text { а) за рахунок державних гарантій підвищення рівня захищеності інтересів } \\
\text { інвесторів; } \\
\text { б) вдосконалення системи стимулювання інвестицій в основний капітал за } \\
\text { рахунок податкових пільг; }\end{array}$ \\
\hline $\begin{array}{c}\text { Інноваційність } \\
\text { підприємництва }\end{array}$ & $\begin{array}{l}\text { а) забезпечення умов для прискорення модернізації техніко-технологічної } \\
\text { бази підприємств; } \\
\text { б) вдосконалення системи стимулювання інноваційної активності } \\
\text { підприємництва; } \\
\text { в) посилення системи захисту права власності та ін.; }\end{array}$ \\
\hline $\begin{array}{l}\text { Виробнича складова } \\
\text { підприємництва }\end{array}$ & $\begin{array}{l}\text { а)підвищення економічної ефективності виробництва і використання } \\
\text { ресурсів; } \\
\text { б) зниження ресурсо - та енергомісткості виробництва; } \\
\text { в) забезпечення рівноправного доступу підприємств до національних } \\
\text { ресурсів, державних закупівель, майна тощо; } \\
\text { г) управління витратами. }\end{array}$ \\
\hline
\end{tabular}

Таким чином, регулювання економічною безпекою підприємництва потребує негайного формування ефективної системи регулювання витратами як чинника економічної безпеки підприємництва. До переваг від імплементації запропонованої системи регулювання витратами підприємництва слід віднести:

1) зведення до мінімального рівня наслідків від негативних змін;

2) зведення до мінімуму факторів невизначеності в майбутньому;

3) виявлення, врахування та визначення міри впливу зовнішніх та внутрішніх факторів, що формують зміни в регулюванні витратами підприємництва;

4) отримання підгрунтя для прийняття стратегічних і тактичних рішень;

5) підвищення керованості системою та поява можливості порівняння різних методик спонукання та контролю за реалізацією різноманітних стратегій забезпечення економічної безпеки підприємництва в частині регулювання витратами підприємництва.

Висновки i перспективи подальших досліджень. Отже, невід'ємною складовою ефективної системи регулювання витратами як чинника економічної безпеки підприємництва ми вважаємо систему контролю та коригування заходів, які необхідно реалізувати для досягнення визначених мети та завдань.

Щодо системи регулювання витратами як чинника економічної безпеки підприємництва, то найбільш дієвим та ефективним є запровадження практики моніторингу стану економічної безпеки підприємництва на всіх рівнях. Такий моніторинг має сконцентровуватися на вектороутворюючих та ключових показниках, котрі спрямовані на:

а) визначення рівня та динаміки індикаторів функціональних складових та інтегрального показника економічної безпеки підприємництва;

б) оцінювання ефективності реалізованих заходів державного регулювання витратами як чинника економічної безпеки підприємництва;

в) аналіз факторів впливу на зміну індикаторів економічної безпеки підприємництва, у тому числі в частині витрат за регіональним та галузевим розподілом.

Здійснення моніторингу дасть змогу не лише визначати ефективність системи регулювання витратами як чинника економічної безпеки підприємництва та вжитих в іiі рамках заходів, але й своєчасно вносити корективи, котрих потребує підприємництво, зважаючи на зовнішні впливи та внутрішній стан.

\section{ПЕРЕЛІК ВИКОРИСТАНИХ ДЖЕРЕЛ}

1. Єрмошенко М. М. Фінансова безпека держави: національні інтереси, реальні загрози, стратегія забезпечення / М. М. Єрмошенко//К.: Київський нац. торг.-екон. ун-т, 2001. - 308 с.

2. Олейников Е.А. Основы экономической безопасности (Государство, регион, предприятие, личность) Е.А. Олейников. - М.: ЗАО «Бизнес-школа «Интер-Синтез», 1997. - 288 с.

3. Пастернак-Таранушенко Г. А. Філософські засади забезпечення економічної безпеки держави (з викладенням основ філософії екосестейту) [Електронний ресурс] / Г. А. Пастернак-Таранушенко - Режим 
доступу до ресурсу: www.niisp.gov.ua.

4. Васильців Т. Г. Фінансово-економічна безпека підприємств України: стратегія та механізми забезпечення: [монографія] / Васильців Т. Г., Волошин В. І., Бойкевич О. Р., Каркавчук В. В., [за ред. Т.Г. Васильціва]. Львів: Арал, 2012. - 386 с.

5. Офіційний сайт Держаної регуляторної служби України [Електронний ресурс] - Режим доступу до pecypcy: http://www.dkrp.gov.ua/.

6. ЗУ «Про ліцензування видів господарської діяльності» [Електронний ресурс] // Законодавство України Режим доступу до ресурсу: http://zakon2.rada.gov.ua/laws/show/222-19.

7. Аналітичний звіт про діяльність ДРСУ за 2015 рік [Електронний ресурс] // Держана регуляторна служба України - Режим доступу до ресурсу: http://www.dkrp.gov.ua/files/bc5ca485b2.pdf.

8. Колісник Г.М. Витрати підприємницького сектора України: методологія та практика: [моногр.] / Г.М. Колісник. - Ужгород: ПП «АУТДОР-ШАРК», 2016. - 360 с.

\section{REFERENCES}

1. Yermoshenko, M.M. (2001). Finansova bezpeka derzhavy: natsional'ni interesy, real'ni zahrozy, stratehiya zabezpechennya [Financial security of the state: national interests, real threats, strategy of providing] - Kiev: Kyyivs'kyy nats. torh.-ekon. [in Ukrainian].

2. Oleynykov, E.A. (1997). Osnovy ékonomycheskoy bezopasnosty (Hosudarstvo, rehyon, predpryyatye, lychnost') [Fundamentals of Economic Security (State, Region, Enterprise, Personality)] - Moscow: ZAO «Byznes-shkola «YnterSyntez». [in Russian].

3. Pasternak-Taranushenko, H.A. Filosofs'ki zasady zabezpechennya ekonomichnoyi bezpeky derzhavy (z vykladennyam osnov filosofiyi ekosesteytu) [Philosophical Principles of Ensuring Economic Security of the State (with the Definition of the Fundamentals of the Ecosystem Philosophy)] niisp.gov.ua Retrieved from: www.niisp.gov.ua [in Ukrainian].

4. Vasyl'tsiv, T.H. Voloshyn, V.I., Boykevych, O.R. \& Karkavchuk, V.V. (2012). Finansovo-ekonomichna bezpeka pidpryyemstv Ukrayiny: stratehiya ta mekhanizmy zabezpechennya [Financial and economic security of Ukrainian enterprises: strategy and mechanisms of provision] T.H. Vasyl'tsiva(Ed.). L'viv: Aral. [in Ukrainian].

5. Ofitsiynyy sayt Derzhanoyi rehulyatornoyi sluzhby Ukrayiny [The official site of the State Regulatory Service of Ukraine]. dkrp.gov.ua Retrieved from: http://www.dkrp.gov.ua/. [in Ukrainian].

6. Zakon Ukrainy Pro litsenzuvannya vydiv hospodars'koyi diyal'nosti [The Law of Ukraine About Licensing of Business Activities] (n.d.). zakon.rada.gov.ua. Retrieved from: http://zakon2.rada.gov.ua/laws/show/222-19. [in Ukrainian].

7. Analitychnyy zvit pro diyal'nist' DRSU za 2015 rik [Analytical report on the activity of DRSU for 2015]

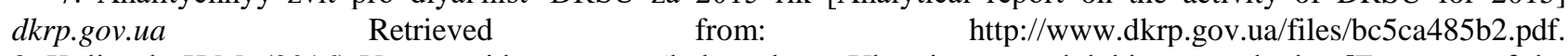
8. Kolisnyk, H.M. (2016) Vytraty pidpryyemnyts'koho sektora Ukrayiny: metodolohiya ta praktyka: [Expenses of the Ukrainian business sector: methodology and practice]- Uzhhorod: PP «AUTDOR-SHARK» [in Ukrainian].

Одержано 15.09.2017 p. 